\title{
Study on Mobile Wave Energy Harvesting System Utilizing Wave Glider Mechanism
}

\author{
Hangil Joe* and Son-Cheol Yu®* \\ "Department of Creative IT Engineering, Pohang University of Science and Technology, Pohang, Korea \\ 웨이브 글라이더 메커니즘을 이용한
이동형 파력발전 시스템의 성능 테스트와 최적 설계에 관한 연구 \\ 조한길 \\ "포항공과대학교 창의 IT 융합공학과
}

KEY WORDS: Wave energy converters 파력 발전, Energy harvesting vehicle 파력 발전 이동체, Wave glider 웨이브 글라이더, Wave energy-harvesting buoy 파력 발전 부이, Self-rectifying wave turbine 자기정류형 웨이브터빈

\begin{abstract}
This paper reports a novel mobile-type wave energy harvesting system. The proposed system adopts a wave glider's propulsion mechanism. A wave glider's blades were mounted on a circular layout and generated a rotational motion. Combining the wave converting system with the wave glider, a mobile floating-type robotic buoy system was developed. It enabled the relocation of the buoy position, as well as station-keeping for long term operation. It had a small size and could efficiently harvest wave energy. A feasibility study and modeling were carried out, and a prototype system was constructed. Various tank tests were performed to optimize the proposed wave energy harvesting system.
\end{abstract}

\section{1. 서 론}

해양에서 장시간 임무 수행을 위해서 선결되어야 하는 문제 중 하나는 에너지 수급 문제이다. 끊임없는 파도와 해류가 존재 하는 해양에서 임무수행은 지속적인 에너지 소모를 요구하지만, 제한된 베터리 용량으로 임무시간의 제약이 있다. 해결책 중 하 나는 신재생 에너지를 활용한 에너지 수급형 무인 시스템을 개 발- 활용하는 것이다. 일반적으로 많이 활용되는 신재생 에너 지원으로는 태양광 발전이 널리 활용되지만, 특수 목적 장기간 임무용 해양 시스템에 활용되기에는 몇 가지 어려움이 있다. 지 속적으로 흔들리는 파도에 의해서 일정한 입사각을 확보하기 어렵고, 해수와 해풍에 의한 오염- 부식으로 효율이 급격히 감 소하는 어려움이 있다. 또한 태양광 발전량은 표면적에 비례하 는데, 크기가 제한되는 시스템의 경우에는 충분한 설계 전력을 공급하지 못할 우려가 존재한다. 이런 단점을 보완하는 해양 신 재생 에너지원으로 파력 발전이 주목을 받고 있다. 해양에서 파 력에너지는 24 시간 활용이 가능하고 지속 가능한 신재생 에너
지원이다. 또한 에너지 밀도가 태양광에 비해 약 10 배 가까이 높고, 기상예보에 따라 예측가능 하므로 에너지 수급 계획을 정 밀하게 세울 수 있는 장점이 있다(Smill, 2008; Falnes, 2007).

파도로부터 에너지를 수급하는 파력발전 장치(Wave energy converter)는 크게 설치 장소에 따라 해안용(On-shore), 근해용 (Near-shore), 원해용(Off-shore)으로 구분된다. 파도의 에너지는 해양에서 멀어질수록 선형 형태의 파도(Linear wave)를 띄며 높 은 에너지 밀도를 가지고, 해안으로 가까워질수록 얕은 수심으 로 인한 해저면과 상호작용으로 에너지 밀도가 감소한다. 파도 의 파장에 비해 수심이 충분히 깊은 심해(Deep sea)의 파도를 수급하는 목적으로 파력발전 장치를 개발하는 것이 유리하지만, 심해의 경우 파력발전장치를 계류(Mooring)하는데 아주 큰 비용 이 소모되므로 경제성면에서 불리하다. 해안에서 멀어질수록 설치비용이 크게 증가하므로 원해용 파력발전 장치는 거의 개 발된 것이 없다. 또한 개발된 대부분의 파력발전 장치는 크기가 크고, 고정형이기 때문에 무인선과 같은 이동형 시스템에 활용 하기 어렵다. 따라서 고정형이 아닌 이동형으로 무인선에 부착

Received 20 July 2018, revised 24 September 2018, accepted 18 October 2018

Corresponding author Son-Cheol Yu: +82-54-279-9504, sncyu@postech.ac.kr ORCID: http://orcid.org/0000-0001-5654-1816 It is noted that this paper is revised edition based on proceedings of KMRTS 2018 in Daejeon

(C) 2018, The Korean Society of Ocean Engineers

This is an open access article distributed under the terms of the creative commons attribution non-commercial license (http://creativecommons.org/licenses/by-nc/3.0) which permits unrestricted non-commercial use, distribution, and reproduction in any medium, provided the original work is properly cited. 
되어 파력에너지 수급이 가능한 새로운 형태의 파력발전 장치 개발이 필요하다.

본 연구에서는 새로운 형태의 파력 발전 장치를 제안한다. 제 안하는 파력 발전 장치는 웨이브 글라이더 메커니즘을 활용하 는 새로운 형태의 파력 발전 장치이다. 부유체와 잠수체로 이루 어져 있고, 부유체는 해수면의 파도를 흡수하여 잠수체로 전달 한다. 잠수체에는 플랩핑(Flapping)이 가능한 블레이드 레이어 (Blade layer)가 상호반전 회전(Counter rotating)을 하도록 배치되 어 있다. 특이한 구조 덕분에 제안하는 파력발전 장치는 해저면 에 고정되지 않은채 파도의 수직 운동을 회전운동으로 변환하 여 전력수급이 가능하다. 따라서 이동형 파력발전 장치로 활용 이 가능하며 설치 및 유지보수가 간편하다.

본 논문에서는 제안하는 파력 발전 장치의 소개와 프로토타 입(Prototype) 개발과정, 그리고 성능테스트 결과를 제시한다. 또 한 실험결과를 토대로 효율 증대를 위한 최적 설계를 위한 방 안에 대해 논의한다.

\section{2. 새로운 파력발전 시스템의 소개}

\section{1 이동식 파력 발전 부이}

부이 시스템은 수상에서 해양 감시 - 계측 - 안보의 보편적 플 랫폼으로 활발히 사용되고 있다. 종래의 부이 기술은 단순하면 서 활용성이 높으나 넓은 바다를 정밀하게 관측하기에는 한계 가 있다. 또한 계류식 부이의 경우 수심이 깊은 심해에는 설치 가 어려우며 높은 비용을 동반한다. 기존 부이시스템의 단점을 보완하고, 부이의 활용 영역을 확장하기 위해 새로운 이동식 파 력 발전 부이 시스템을 제안했다(Fig. 1)(Joe et al., 2015).

제안하는 부이시스템은 무어링 없는 정점 유지 기술로 수심 이 깊은 해역에서도 저비용으로 설치가 가능하다. 또한 고정되 지 않았기 때문에 조사지점의 이동이나 재배치가 용이하다. 장 시간 정점 조사의 경우 태풍 등 해양 재난에 유실될 가능성이 높기 때문에 해양 재난 회피 기동이 필수로 요구된다. 제안하는 부이 시스템은 정밀 펌프로 인한 부력 조절 장치로 잠수를 통 한 해양 재난 회피 기동이 가능하다. 일반적으로 수면의 파도 에너지는 수심에 따라 지수함수적으로 감소를 하며, 파도의 반 파장 아래 수심에서는 영향이 미미하다. 이 수심을 파랑 작용
한계 심도(Wave base)라고 한다. 해양 재난 발생시 시스템의 파 랑 작용 한계 심도까지 잠수를 통해 바람과 파도에 의한 손상 을 최소화할 수 있다.

이동식 부이 시스템은 정점 유지와 이동성을 제공하는 추력 발생 장치와 해양 재난 회피를 위한 부력 조절 장치로 인해 많 은 에너지를 소비하게 된다. 배터리의 용량은 제한적이므로 장 시간 임무 수행을 위해서 추가적으로 에너지를 수급할 수 있는 발전 시스템이 필요하다. 이런 이유로 새로운 파력 발전 장치를 제안하게 되었다(Joe et al., 2015).

\section{2 새로운 파도에너지 수급 시스템}

제안하는 파력 발전 시스템은 웨이브 글라이더(Wave glider)의 메커니즘을 응용한다(Fig. 2). 웨이브 글라이더는 파력 에너지를 활용하여 추진력을 생성하는 수상 플랫폼으로 에너지 소모를 최 소한으로 하여 추력을 생성한다(Daniel et al., 2011; Willcox et al., 2009; Bingham et al., 2012). 웨이브 글라이더는 수면에 부유하는 부유체와 잠수체로 구성되는데, 부유체는 파도의 상하 움직임을 받아 연결된 테더(Tether)에 의해서 잠수체로 전달된다. 부유체의 상하 움직임이 전달된 잠수체는 일렬로 배열된 플랩형태의 블레 이드에 의해서 추력을 생성하게 되고, 전기 에너지 소모 없이 앞 으로 이동할 수가 있다(Hine et al., 2009).

제안하는 새로운 형태의 파력발전 시스템(웨이브 터빈, Wave turbine system)은 웨이브 글라이더의 메커니즘을 차용하여 파도 의 상하 운동을 회전운동으로 전환한다. 웨이브 터빈은 수면에 서 파도에너지를 흡수하는 부유체(Floating body)와 잠수체 (Submerged body)로 구성된다. 부유체와 잠수체는 테더로 연결 되어 부유체의 운동에너지가 잠수체로 전달 될 수 있게 구성되 어 있다(Fig. 3). 부유체와 잠수체간의 테더의 에너지 전달을 극 대화하기 위해 잠수체는 파도의 영향이 거의 없는 파랑 작용 한계 심도(Wave bas)e에 위치하게 설계된다. 파랑 작용 한계 심 도(Wave base)에서는 깊이에 따라 지수함수적으로 감소하는 파 도 에너지가 거의 작용하지 않으므로(Dean and Dalrymple, 1991) 부유체의 상하 운동 에너지는 잠수체로 극대화 되어 전달 될수 있다. 부유체는 파도의 에너지를 최대한 흡수하기 위해 파도의 공진 주파수와 유사하도록 설계가 되며, 컴퓨터, 센서류, 전기 장치, 통신 모듈, 충전 시스템이 탑재가 된다. 잠수체는 터빈과
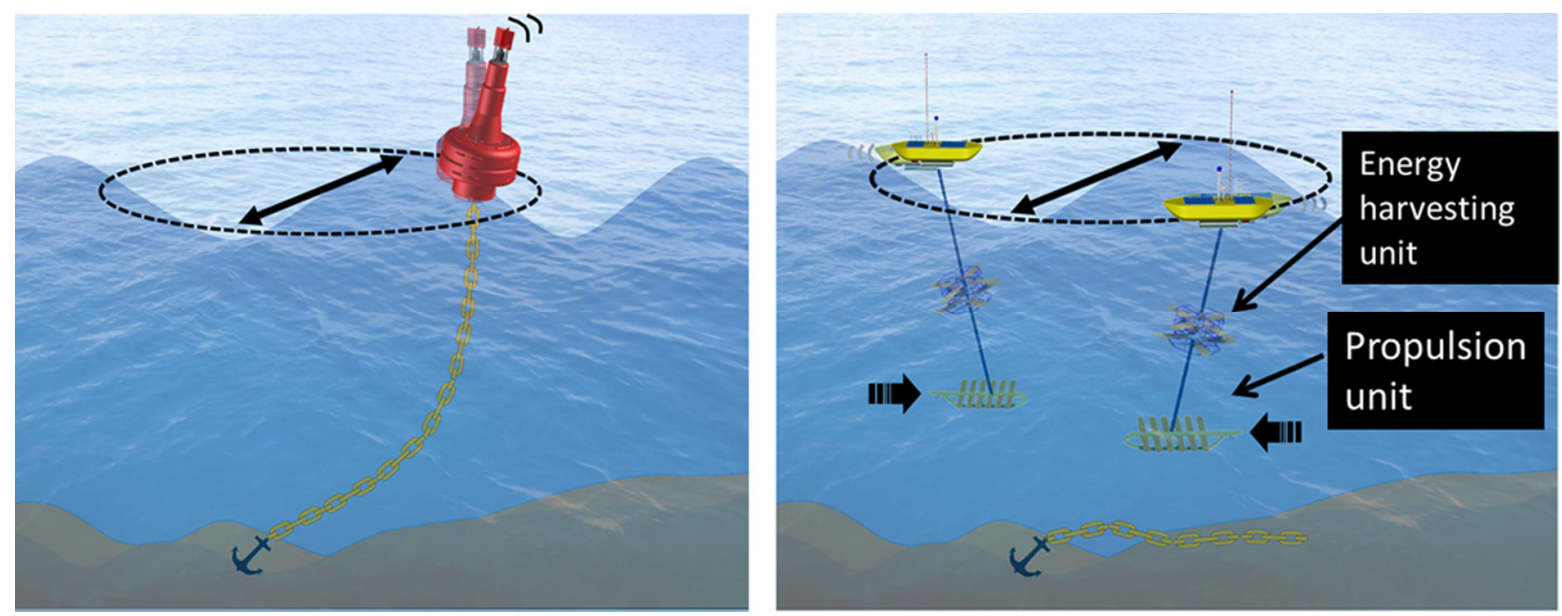

Fig. 1 Concept of energy harvesting robotic buoy system 


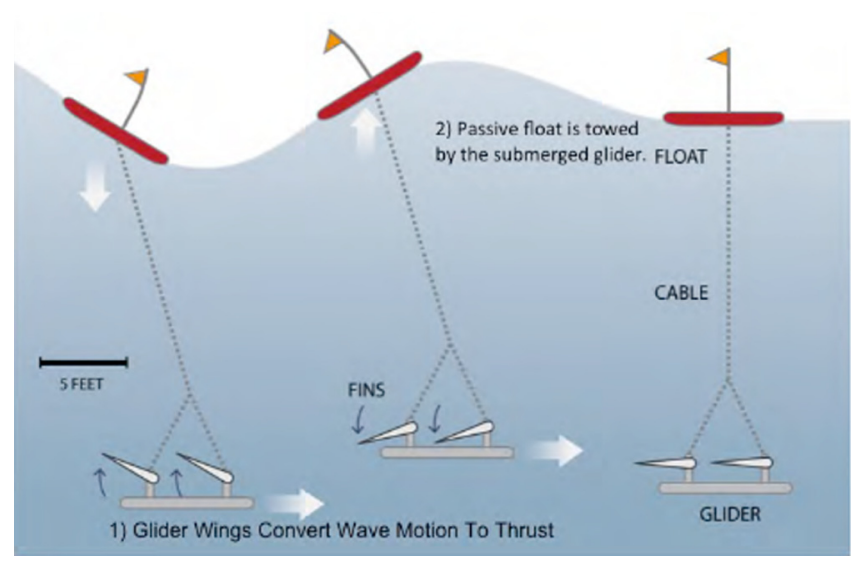

Fig. 2 Mechanism of the Wave Glider

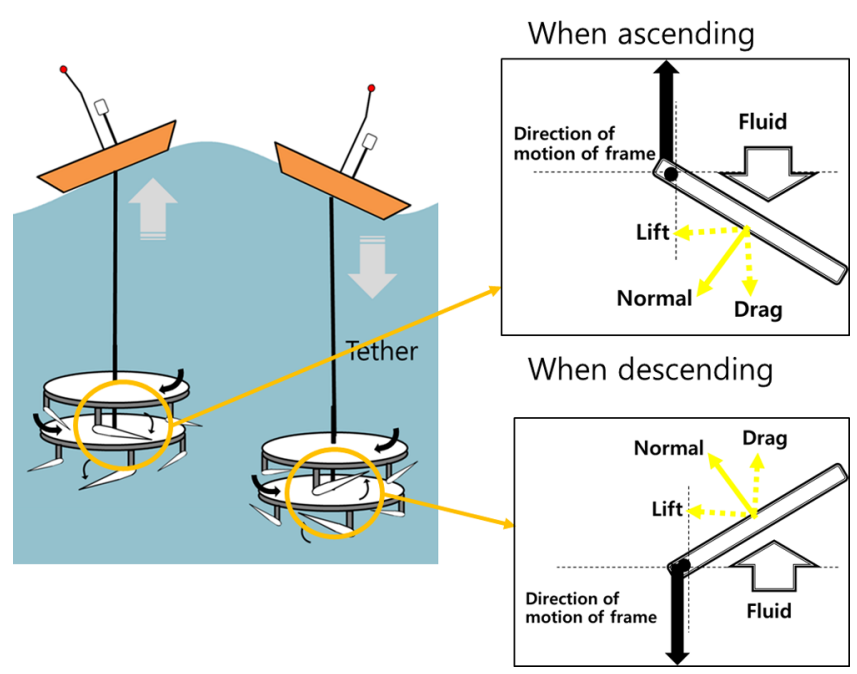

Fig. 3 Mechanism of the proposed wave energy harvesting system

유사한 원형 형태로, 파도의 상하 에너지를 회전운동으로 전환시 키는 플랩형태의 블레이드가 원형 프레임에 부착되어 있고, 회전 중심에 발전기가 부착되어 발전을 하는 형태로 구성된다. 잠수체 는 2개의 블레이드 레이어(Blade layer)로 구성이 되어 두 개의 블레 이드가 상호 이중반전 회전(Counter rotating)하도록 설계 되었다. 따라서 회전으로 발생하는 모멘트(Moment)를 최소화하고, 두 레이
어 사이에 토크가 최대가 되도록 설계가 되었다. 각 레이어에 설치 되는 블레이드는 플랩 형태로 제작 및 설치되며, 일정 각도 내에서 펄럭이며 받음각이 변할 수 있게 설계되었다. 예를 들어 파도에 의해 잠수체가 위로 힘을 받으면, 블레이드는 위에서 아래쪽 방향 으로 저항력을 받아 음의 받음각을 가지게 되고, 반대의 경우 아래 에서 위쪽으로 저항력을 받아 양의 받음각을 가지게 된다. 블레이 드의 이런 특징에 의해 잠수체의 터빈 구조체는 파도의 수직 움직 임 방향에 무관하게 한 방향으로만 회전하는 자기정류형(Selfrectifying) 회전을 실시하게 된다(Joe et al., 2015).

\section{3. 프로토타입 개발 및 성능 테스트}

\section{1 프토로타입 개발}

제안하는 파력발전 시스템은 복잡한 형상으로 인해 시뮬레이 션을 위한 정확한 모델링이 어렵다. 새로운 파력발전 시스템의 성능 테스트와 최적화를 위한 데이터 획득을 위해 하드웨어 프 로토타입을 우선 개발 하였다(Fig. 4). 하드웨어는 2개의 로터 레이어(Rotor layer)로 구성되어 있으며, 두 레이어는 블레이드가 서로 반대 방향으로 부착되어 상호 반전 회전을 하도록 제작 되었다. 로터 프레임에는 블레이드가 탈부착이 용이한 형태로 제작되어 다양한 형태의 블레이드를 테스트하기 유리하게 제작 되었다. 상호반전 회전 축은 Fig. 5와 같이 터빈 축을 설계하여 터빈 축의 3 개의 파트(축 하단, 실린더, 축 상단)가 독립적 회전 이 가능하게 하였다. 이를 통해 전력이 전달되는 전선의 꼬임을 방지하였고 상호반전 회전을 구현하였다. 개발된 프로토타입의 주요 치수 및 사양은 Fig. 4와 Table 1에 나타내었다. 프로토타 입 주요 치수의 기준은 성인남자 2 명이 실험을 수행할 수 있는 크기와 무게를 기준으로 하여 $35 \mathrm{~kg}$ 내외로 제작하였다. 축 실린 더 내부에는 웨이브 터빈의 성능을 모니터링 할 수 있는 엔코 더와 발전기를 장착하였고, 수직운동을 관측하기 위해 압력계 를 부착하였다. 센서 정보는 축 상단의 슬립링을 통해 수면의 부유체 제어 박스로 전달되도록 제작 하였다. 부유체에는 제어 박스가 위치하며, 제어박스에는 데이터 처리를 위한 Arm 기반 $\mathrm{MCU}($ Micro controller unit)가 있으며, 전력 측정을 위한 부하저 항이 있다. 또한 데이터 전송을 위한 무선 모듈과 전체 시스템 을 통제하기 위한 컴퓨터와 배터리가 구성되었다.
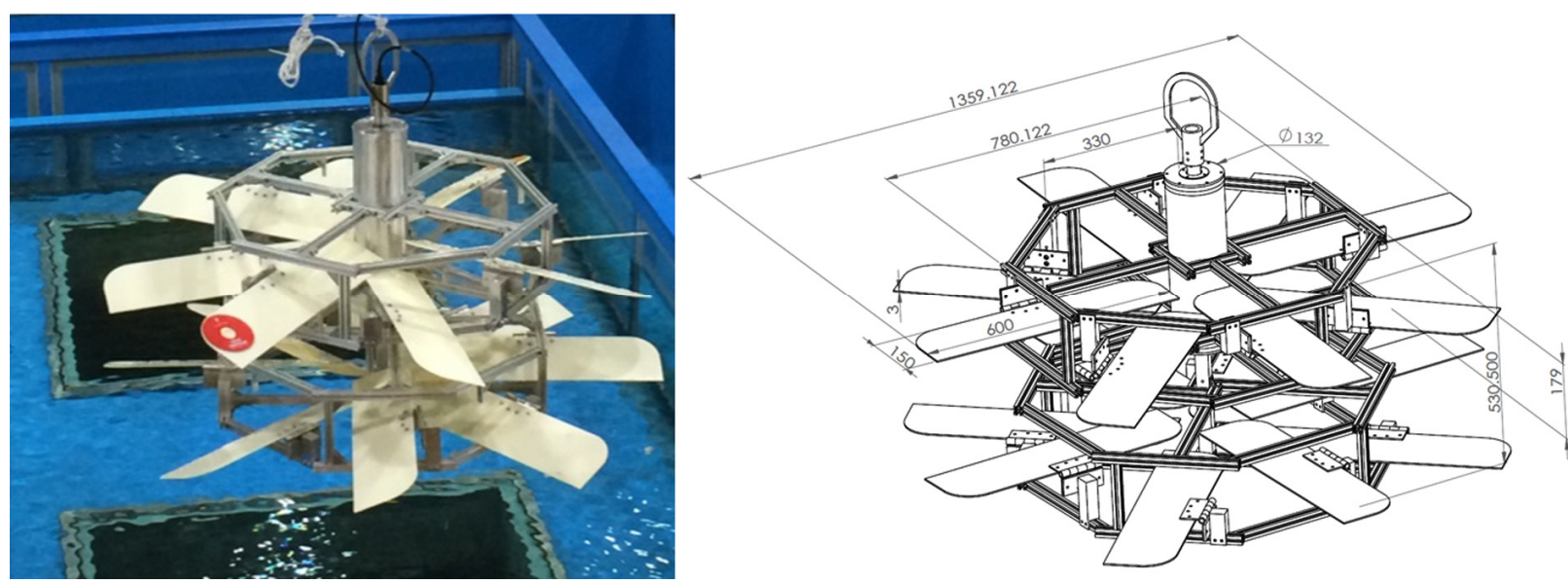

Fig. 4 Prototype fabrication 

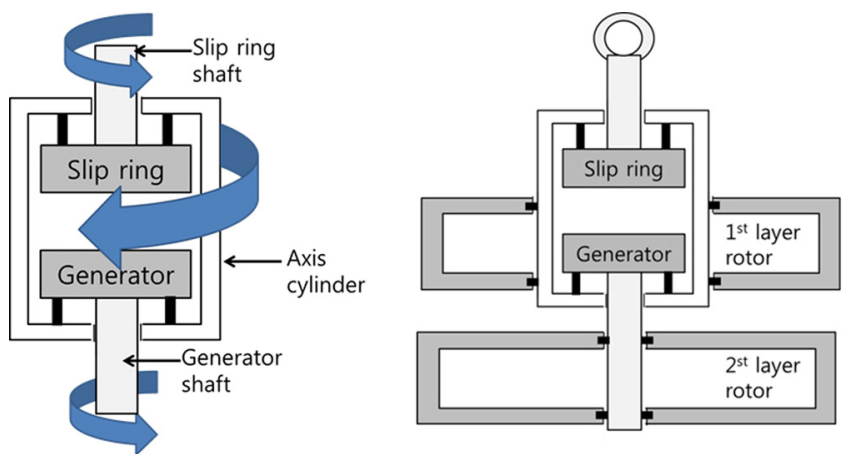

Fig. 5 Turbine axis configuration and layout of Wave turbine structure

Table 1 Specification of the prototype

\begin{tabular}{ll}
\hline \hline \multicolumn{1}{c}{ Parameters } & \multicolumn{1}{c}{ Values } \\
\hline Weight & $35 \mathrm{~kg}($ air $)$, \\
Blade's material & $\mathrm{ABS}$ and $\mathrm{AL}$ changeable \\
Blade's dimension & $60 \times 15 \times 0.3 \mathrm{~cm}(\mathrm{~L} \times \mathrm{D} \times \mathrm{W})$ \\
Blade's layout & 8 blades $\times 2$ layers \\
\hline
\end{tabular}

\section{2 성능 테스트}

\subsection{1 수조 테스트}

개발된 프로토타입의 성능 테스트를 실내 수조에서 실시하였 다. 실험장소는 영덕 학생 해양 수련원 수조에서 실시하였다.
파도의 움직임을 구현하기 위해 AC(Alternating current) 모터와 크랭크-슬라이더 구조로된 파형 생성 장치(Locomotive motion actuator)를 개발하였다. 실험 환경은 Fig. 6과 같이 구축하였다. 웨이브 터빈의 회전 속도는 축실린더 내부의 엔코더 파형을 $\mathrm{MCU}$ 로 계측을 하였고, 발전기의 생성 전력은 부하저항과 $\mathrm{MCU}$ 를 사용하여 모니터링을 하였다. 파형 생성 장치는 $0.4 \mathrm{~m}$ 의 파고 로, $0.5 \mathrm{~Hz}$ 주파수로 파형을 생성하였다. 터빈 실린더 상단에 부 착된 압력계를 통해 웨이브 터빈의 수직 운동은 계측이 되었다.

테스트 결과 생성된 최고 전력은 $8 \mathrm{~W}$ 였고, 평균 $1.67 \mathrm{~W}$ 의 전력 이 생성되었다(Fig. 7). 터빈의 회전속도는 평균 20rpm으로 지속 적인 회전이 관측되었다.

\subsection{2 공학수조}

서로 다른 블레이드가 웨이브 터빈 성능에 미치는 영향을 확인 하기 위해 공학 수조에서 블레이드를 바꿔가며 성능 테스트를 실 시하였다. 실험은 한국로봇융합연구원 공학수조에서 실시하였 다. 실험세팅은 Fig. 8과 Table 2에 나타낸 것과 같다. 테스트에 사용한 블레이드의 재료는 $\mathrm{ABS}$ (Acrylonitrile butadiene styrene)와 알루미늄 두가지이며, 알루미늄 블레이드의 경우 크기를 $100 \times$ $15 \times 0.2,50 \times 14 \times 0.3,50 \times 8 \times 0.3(\mathrm{~L} \times \mathrm{W} \times \mathrm{D}, \mathrm{cm})$ 세가지로 바꿔가며 실 험을 실시하였다. $\mathrm{ABS}$ 블레이드의 크기는 $60 \times 15 \times 0.3$ 이었다. 파 형생성장치를 이용하여 실험을 실시하였고, 파고는 $0.3 \mathrm{~m}$, 주파수 는 $0.33,0.25,0.17 \mathrm{~Hz}$ 로 다양하게 변조해가며 테스트를 진행하였 다. 본 테스트에서는 발전량을 계측하기보다 다양한 하드웨어 세
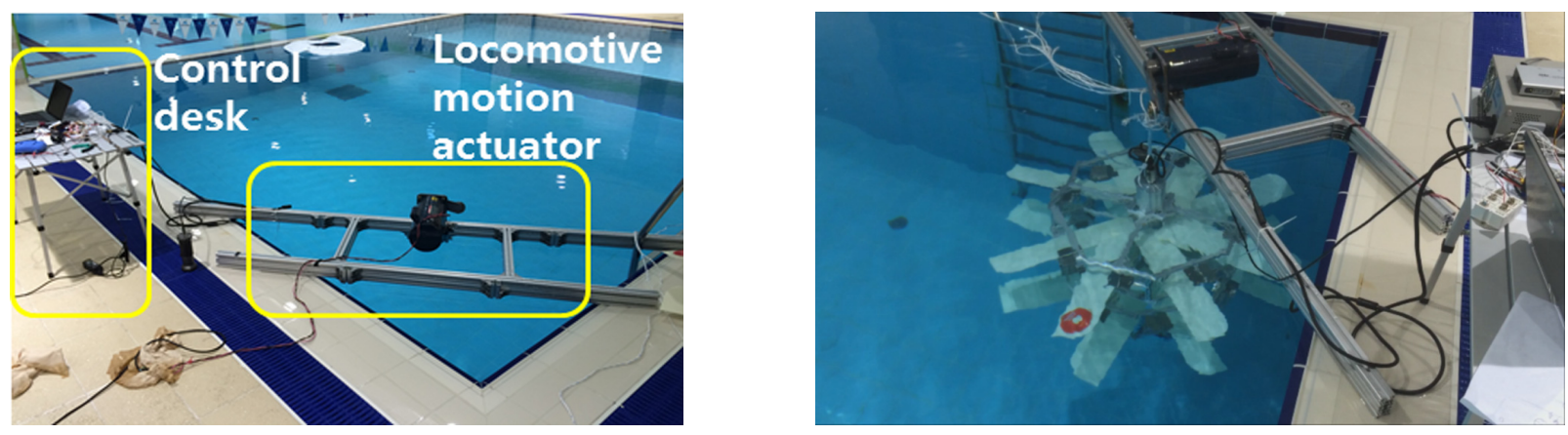

Fig. 6 The electrical power generation test using the prototype of Wave turbine. The locomotive motion actuator to emulate wave motion (left) and the experimental setup (right).
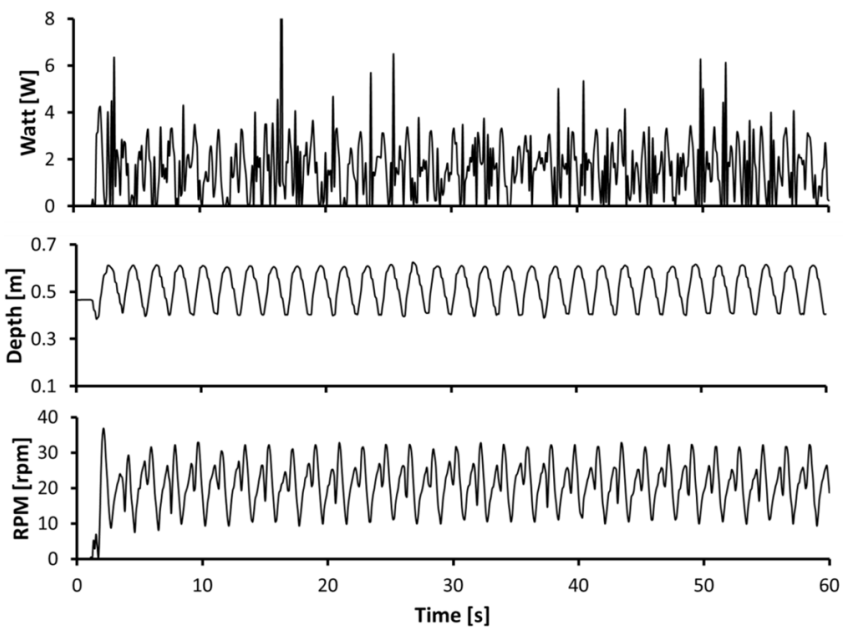

Fig. 7 The obtained data in the electrical power generation test. 

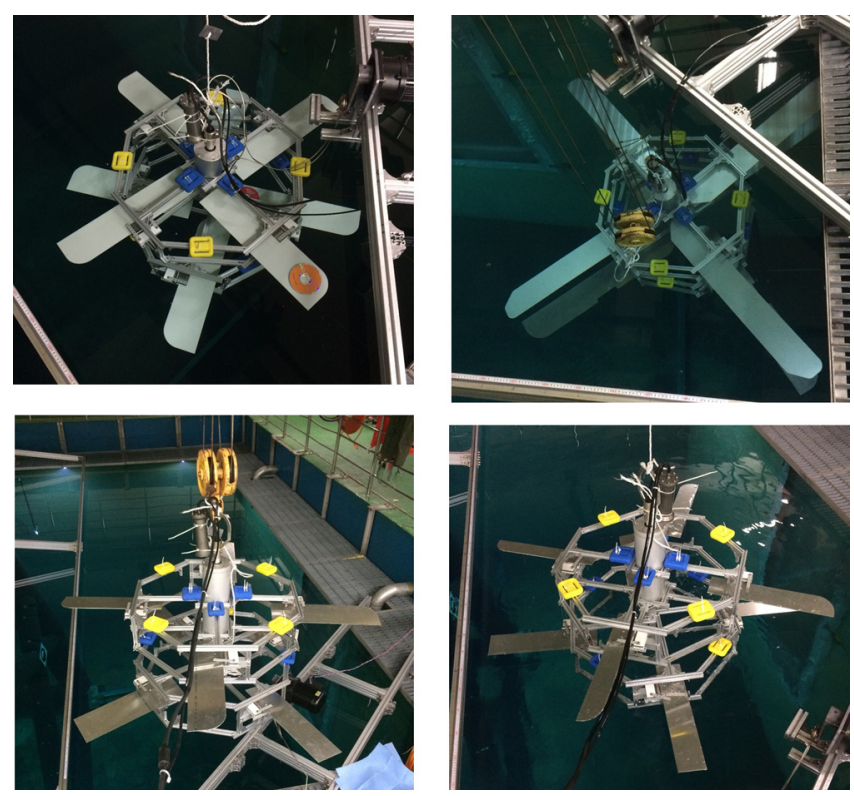

Fig. 8 Experimental configuration for tank test using 4 differenct blades

Table 2 Parameters of Wave turbine blade used for simulation and tank test

\begin{tabular}{lllll}
\hline \hline Blade properties & Case 1 & Case 2 & Case 3 & Case 4 \\
\hline Material & ABS & Aluminum & Aluminum & Aluminum \\
Length [m] & 0.6 & 1 & 0.5 & 0.5 \\
Width & 0.15 & 0.15 & 0.14 & 0.08 \\
\hline
\end{tabular}

Table 3 Resulted mean rotational speed[rpm] in experiment

\begin{tabular}{lccc}
\hline \hline & Period 3s & Period 4s & Period 6s \\
\hline Case 1 & 16.47 & 11.66 & 5.57 \\
Case 2 & 19.21 & 15.72 & 5.84 \\
Case 3 & 10.89 & 6.21 & 2.67 \\
Case 4 & 7.48 & 3.36 & 1.21 \\
\hline
\end{tabular}

팅에서 터빈의 동적 거동이 어떻게 달라지는지를 확인하기 위해 실시되었다. 따라서 회전속도를 위주로 계측하였다. 실험결과는 Table 3에 정리하였다. 서로 다른 블레이드 크기에 따라 파도의 주기를 3초에서 6초로 변화 시켜가며 평균 회전 속도를 기록하였 다. 평균 회전 속도는 Case 2에서 가장 빨랐고, 파도의 주기가 길 어질수록 감소하였다.

\subsection{3 조파수조 테스트}

첫번째 수조 테스트와 공학수조 테스트에서는 파형 생성 장 치를 사용하여 실험을 하였기 때문에, 실제 파도에서 테스트 진 행의 필요성이 있었다. 따라서 조파수조에서 개발된 프로토타 입의 성능을 테스트하였다. 실험장소는 수산과학원의 조파수조 에서 실시하였다. 실험 조건은 수조 실험과 동일하였는데, 조파 수조에서 실해역과 유사한 조건을 부여하기 위해 무선 모듈을 사용하여 데이터 획득을 하였다. 부유체는 컴퓨터, 무선모듈을
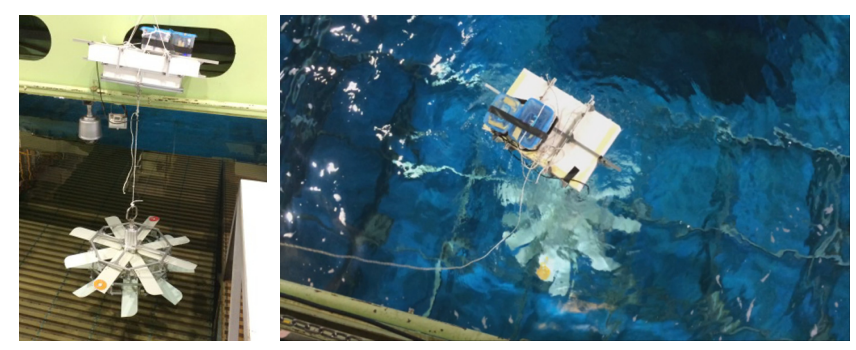

Fig. 9 Electrical power generation test using the prototype; launching (left) and the wave turbine in wave (right)

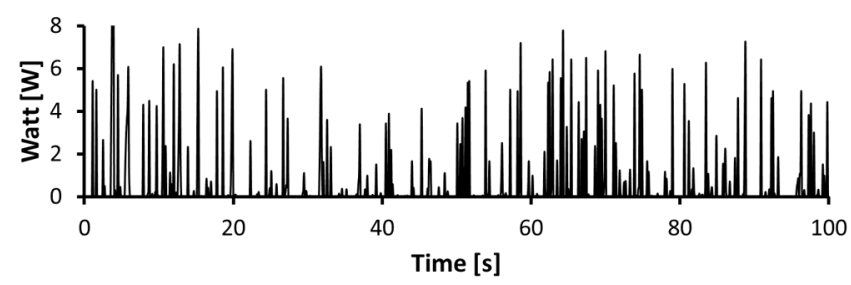

Fig. 10 Generated electrical power estimated in power generation test.

포함하는 제어박스와 부력제, 배터리로 구성되었다. 테더의 길 이는 약 $2.5 \mathrm{~m}$ 로 조절하였다. 조파수조의 파도 조건은 파고 $0.3 \mathrm{~m}$ 주파수는 $0.41 \mathrm{~Hz}$ 로 파도를 생성하였다.

실험 세팅은 Fig. 9에 나타내었다. 실험결과 최고 전력은 $8 \mathrm{~W}$ 였고, 평균 생성 전력은 $0.52 \mathrm{~W}$ 였다(Fig. 10).

\section{4. 최적 설계를 위한 고찰}

\section{1 에너지 변환에 대해}

웨이브 터빈의 에너지 변환 과정은 Fig. 11 과 같다. 부유체가 흡수한 파도에너지를 테더가 잠수체에 전달하고, 잠수체는 상하 운동을 회전운동으로 변환한다. 회전운동은 발전기에 의해 전기 에너지로 최종 변환된다. 각 에너지 변환 단계에서 효율 극대화 를 위해 해결해야 하는 이슈들이 있다. 첫번째는 동적인 거동을 극대화하는 부분이다. 동적 거동을 극대화는 크게 로터 레이어 의 저항력을 줄이고, 블레이드로부터 생성되는 추력을 강화하는 것으로 나누어 진다. 블레이드의 추력 강화는 적절한 블레이드 를 선정하는 것부터, 플랩핑 운동의 적절한 제한 각도를 설정하 는 것을 포함한다. 웨이브 터빈은 블레이드가 일정한 각도로 고 정된 것이 아니라, 일정 제한 범위 내에서 플랩핑 운동을 한다. 블레이드가 각도 제한으로 도달하기 까지 천이 상태(Transient) 가 존재하며 이때는 에너지 수급율이 감소한다. 블레이드의 천 이 상태 시간을 줄이기 위해 블레이드 각도 제한을 작게 하면 생성되는 토크 또한 감소하기 때문에 최적의 값을 조사할 필요 가 있다. 두번째는 블레이드의 형상과 크기, 재료이다. 블레이드 의 단명 형상은 유체역학적으로 양- 항력 계수를 개선하므로 중 요하고, 블레이드의 길이와 폭의 비율 또한 적정한 비율로 선정 되어야 한다. 기존의 터빈과 다른점은 블레이드의 재료이다. 블 레이드의 받음각이 파도의 상하 움직임에 따라 변하므로 블레이 드가 이를 잘 추종해야한다. 블레이드의 재료 밀도가 크면 웨이 브 터빈이 가라앉을 때 플랩핑이 잘 일어나지 않으므로 이를 고 


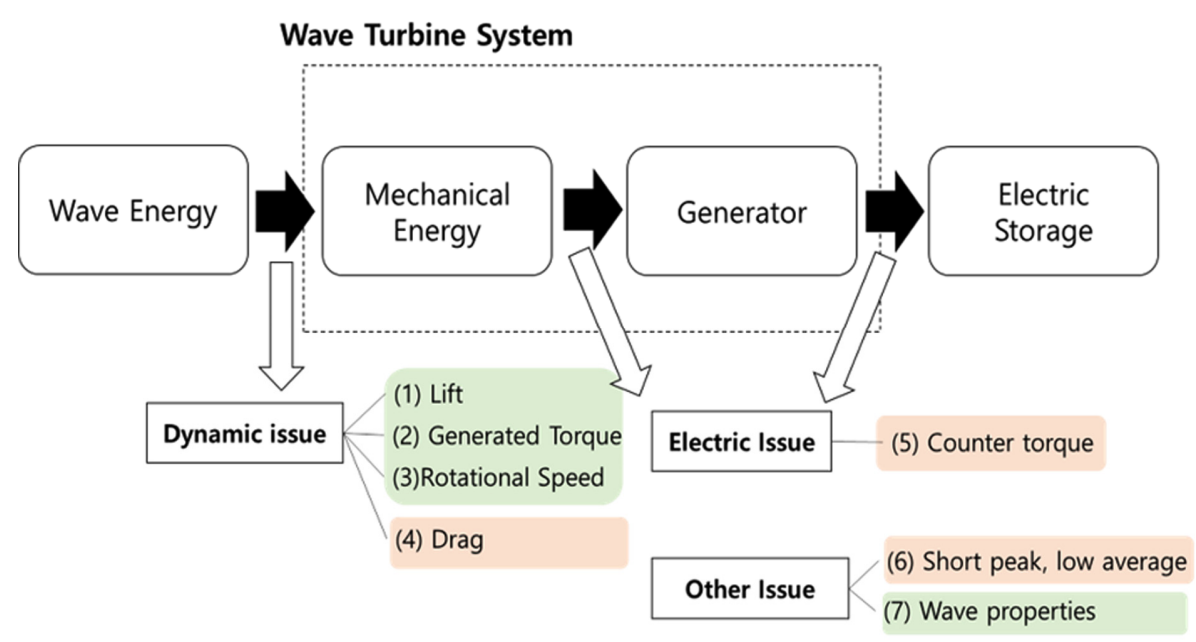

Fig. 11 Diagram for energy conversion of Wave turbine

려한 블레이드 선정이 필요하다. Table 3에 표시된 다양한 블레 이드에서 실험결과를 보면, 크기가 비슷한 Case 1과 Case 3의 차 이는 확연하게 드러난다. 밀도가 큰 알루미늄의 무게로 인해 웨 이브 터빈이 아랫방향으로 이동시 블레이드 플랩핑에 시간이 걸 리게 되고, 이것이 바로 효율의 감소로 나타났다.

세번째는 파력발전 특유의 일정하지 않은 전력 생성이다. 앞 의 실험에서 파도의 파형 생성 장치를 사용한 경우는 지속적인 상하 운동으로 꾸준한 전력 생성이 가능하였지만, 실해역의 파 도는 다양한 주파수의 파도의 중첩으로 불규칙파(Irregular wave) 형태를 띄므로 연속적 발전이 어렵다. 짧은 시간내에 순 간적인 발전전력은 크지만 평균화 하면 아주 낮기 때문에 생성 된 순간 고전력을 저장하는 기술이 필수로 요구된다. 반면 규칙 파가 생성되는 조파수조에서 실험결과가 순간적인 고전력은 발 생하였으나, 평균적으로 낮아진 것 에는 다음과 같은 이유가 있 다. 조파수조의 수심이 충분하지 못하여 부유체와 잠수체가 함 께 파도의 영향을 받았기 때문이다. 이로 인해 테더로 인해 당 겨지는 힘이 극대화 되지 못하였고, 효율 감소로 이어졌다. 또 한 부유체의 공진 주파수가 파도 공진 주파수와 일치하는 것이 중요한데, 조파수조 실험에서는 최적화된 하드웨어 세팅이 이 루어지지 못했다. 다음 장에서는 수식 모델링을 통해 최적 설계 변수에 대해 논의 하고자 한다.

\section{2. 모델링을 통한 최적 설계 방안}

파력발전에 이용되는 파도는 다양한 원인에 의해서 생성되나 가장 빈번히 발생하고, 에너지 총량이 큰 원천은 바람이다. 풍파 (Wind wave)는 주로 주기가 1초에서 10초 정도로 먼바다에서 생 성되어 연안까지 전달되어 온다. 전달과정에서 단파는 소멸되고, 장파만 중력과 표면 장력에 의해 연안까지 전달된다. 연안 부근 에서 수심이 파장에 비해 얁아지면 해저면과 마찰에 의해 파도 에너지는 감소하게 되고, 연안에서 쇄파가 일어난다. 제안하는 파력발전 시스템은 연안에서 충분히 먼 심해 해역에 설치가 목적 이므로, 수심이 파장에 비해 깊고 $(h>\lambda / 2)$, 충분히 성장된 파랑 (Fully developed sea)에서는 파도 모델은 선형파 이론(Linear wave theory)을 만족한다. 따라서 파력 발전 부이에 작용하는 파력은 삼각 함수로 모델링이 된다. 수면에서 파도를 받는 부유체의 형
상을 직육면체로 가정하고, Strip theory(McCormick, 1973)를 적용 하면 부유체가 받는 파력 $F_{z}$ 와 수면위 물체의 수직 변위 $Z_{1}$ 은 다 음과 같이 표현된다.

$$
\begin{aligned}
& F_{z}=F_{0} \cos (\omega t) \\
& F_{0}=\frac{\rho g H B \lambda}{2 \pi}\left(e^{-2 \pi d_{w} / \lambda}+1\right) \sin \left(\frac{\pi L}{\lambda}\right) \\
& Z_{1}=\frac{\left(F_{0} / \rho g A_{w p}\right) \cos \left(\omega t+\gamma-\sigma_{z}\right)}{\sqrt{\left(1-\omega^{2} / \omega_{z}^{2}\right)^{2}+\left(2 \delta_{z} \omega / \omega_{z}\right)^{2}}}
\end{aligned}
$$

여기서 $\omega$ 는 각주파수, $\omega_{z}$ 는 공진 주파수, $\rho$ 는 물의 밀도, $g$ 는 중력가속도, $H$ 는 파고, $B$ 부유체의 폭, $\lambda$ 는 파장이다. 또한, $d_{w}$ 는 부유체의 흘수, $\delta_{z}$ 는 감쇠 계수, $\sigma_{z}$ 는 감쇠 계수의 영향을 받 는 위상각, $A_{w p}$ 는 수선 면적이다. 단, 부유체가 주변 파도의 공 진 주파수와 거의 일치하도록 설계되었다고 가정하면, 파력을 받는 부유체의 거동을 식 (4)와 같이 단순화 시킬 수 있다.

$$
Z_{1}=0.5 H \cos \left(\frac{2 \pi}{T} t\right)
$$

웨이브 터빈은 부유체와 잠수체, 두 질량체로 모델링이 되며, 둘은 테더로 연결되어 있다. 부유체가 파력을 받으면 테더를 통 해 잠수체로 전달이 되고, 잠수체의 저항력, 관성력 등이 다시 부유체의 동적 거동에 영향을 미친다. 파력을 받는 부유체와 잠 수체의 수직 운동은 다음과 같이 묘사가 된다.

$$
\begin{aligned}
& \left(m_{f}+m_{f a}\right) \ddot{Z}_{f}=F_{z}-F_{T}+F_{r} \\
& \left(m_{s}+m_{s a}\right) \ddot{Z}_{s}=F_{T}-F_{D}\left(\dot{Z}_{s}, \dot{\psi}_{u}, \dot{\psi}_{i}, \delta_{u}, \delta_{i}\right)-F_{g}+F_{b}
\end{aligned}
$$

여기서 $m_{f}$ 와 $m_{f a}$ 는 부유체의 질량과 부가질량, $m_{s}$ 와 $m_{s a}$ 는 잠 수체의 질량과 부가질량이다. $F_{T}$ 는 테더에 의한 장력을 의미하 고, $F_{r}$ 은 부유체의 복원력, $F_{g}$ 와 $F_{b}$ 는 중력과 부력에 의한 힘을 
나타낸다. $F_{D}$ 는 잠수체에 작용하는 저항력을 의미한다. $F_{D}$ 는 잠수체의 수직 속도 $\dot{Z}_{s}$, 상단 레이어의 회전 속도 $\dot{\psi}_{u}$, 하단 레 이어의 회전속도 $\dot{\psi}_{i}$, 블레이드의 받음각 제한 $\left(\delta_{u}, \delta_{i}\right)$ 에 따라 달 라진다. 이를 정확하게 모델링하기는 아주 어려우므로, 잠수체 의 수직방항 저항력은 블레이드의 수직방향 저항력, 프레임의 수직방향 저항력의 합만 고려하였다.

잠수체의 상 - 하 로터 레이어의 회전은 다음과 같이 표현된다.

$$
\begin{aligned}
& \left(I_{u}+I_{u a}\right) \ddot{\psi}_{u}=N_{b}\left(\dot{Z}_{s}, \dot{\psi}_{u}, \delta_{u}\right)-D_{u}\left(\delta_{u}, \dot{\psi}_{u}\right)-F_{f}-F_{g e} \\
& \left(I_{i}+I_{i a}\right) \ddot{\psi}_{i}=-N_{b}\left(\dot{Z}_{s}, \dot{\psi}_{i}, \delta_{i}\right)+D_{i}\left(\delta_{i}, \dot{\psi}_{i}\right)+F_{f}+F_{g e}
\end{aligned}
$$

여기서 $I_{u}$ 와 $I_{u a}$ 는 상방 로터 레이어의 관성모멘트와 부가질량 관성모멘트이고, $I_{i}$ 와 $I_{i a}$ 는 하방 로터 레이어의 관성모멘트와 부가질량 관성 모멘트이다. $\ddot{\psi_{u}}$ 와 $\ddot{\psi}_{i}$ 은 각 로터의 각가속도이고, $\dot{\psi}_{u}$ 와 $\dot{\psi}_{i}$ 는 각속도이다. $N_{b}$ 는 블레이드에 의해 생성되는 추력인 데, 추력은 잠수체의 수직 속도, 로터블레이드의 회전속도, 그리 고 블레이드의 받음각 제한에 따라 달라지는 함수로 표현된다. 로터 레이어의 회전은 블레이드의 형태와 받음각 제한에 따라 면적이 달라지므로 저항력은 $D_{u}\left(\delta_{u}, \dot{\psi}_{u}\right)$ 와 같은 함수로 표현된 다. $F_{f}$ 는 마찰력이고, $F_{g e}$ 는 발전기 토크이다.

각 레이어에 설치된 블레이드의 플랩핑 운동은 식 (9)-(10)으 로 표현된다.

$$
\begin{aligned}
& \left(I_{b}+I_{b a}\right) \ddot{\delta}_{u}=D_{b u}\left(\dot{Z}_{s}, \delta_{u}, \dot{\psi}_{u}\right)+\left(m_{b} \ddot{Z}_{s}+m_{b} g-F_{b b}\right) r_{b} \cos \left(\delta_{u}\right) \\
& \left(I_{b}+I_{b a}\right) \ddot{\delta}_{i}=-D_{b i}\left(\dot{Z}_{s}, \delta_{i}, \dot{\psi}_{i}\right)+\left(m_{b} \ddot{Z}_{s}+m_{b} g-F_{b b}\right) r_{b} \cos \left(\delta_{i}\right)
\end{aligned}
$$

여기서 $I_{b}$ 와 $I_{b a}$ 는 상방 로터 레이어의 관성모멘트와 부가질량 관성모멘트이고, $\ddot{\delta}_{u}$ 와 $\ddot{\delta}_{i}$ 은 블레이드의 각가속도이다. $m_{b}$ 는 블 레이드의 질량, $F_{b b}$ 는 블레이드의 부력, $r_{b}$ 는 모멘트 암이다. $D_{b u}\left(\dot{Z}_{s}, \delta_{u}, \dot{\psi}_{u}\right)$ 는 저항력인데, 회전 중심으로 블레이드 폭의 적 분으로 구해진다.

웨이브 터빈에 설치된 발전기의 토크는 다음 식에 의해서 표 현이 된다.

$$
\begin{aligned}
& F_{\geq}=\text {ratio } \cdot K_{t} \cdot \frac{<\text { ratio } \cdot K_{e} \cdot\left(\dot{\psi}_{u}-\dot{\psi}_{i}\right)-V_{\text {for ward }}}{\left(R_{g}+R_{\text {load }}\right)} \\
& \approx 4 \cdot K_{\geq} \dot{\psi}^{2}
\end{aligned}
$$

여기서 ratio는 발전기 앞단에 부착된 증속기의 기어비이고, $K_{t}$ 와 $K_{e}$ 는 발전기 상수이다. $V_{\text {for ward }}$ 는 정류기의 순전압(Forward voltage)이고, $R_{g}$ 와 $R_{\text {load }}$ 는 각각 발전기 내부 저항과 부하 저항 이다. 여기서 $\dot{\psi}_{u} \approx \dot{\psi}_{i}$ 라고 가정하고, $V_{\text {for ward }}$ 가 아주 작다고 가 정하면 식 (12)와 같이 간략화 된다. 발전기에 의해 변환된 에너 지는 다음과 같이 나타내어진다.

$$
P_{P T O}=F_{\geq} \cdot\left(\dot{\psi}_{u}-\dot{\psi}_{i}\right)
$$

웨이브 터빈의 구조상 에너지 효율에 큰 영향을 미치는 요소 는 플랩 형태의 블레이드이다. 블레이드에 의해서 생성되는 토 크 $N_{b}$ 는 블레이드의 형상 단면 또는 길이, 폭의 함수로 모델링 될수 있으며, 다음과 같이 나타낼 수 있다.

$$
N_{b}=n \cdot \int \vec{r}_{i} \times\left(\overrightarrow{d F}_{d i}+d \overrightarrow{F F}_{l i}+d \overrightarrow{d F}_{a i}\right)
$$

여기서 $\vec{r}_{i}$ 는 로터 회전 중심에서 $\mathrm{i}$ 번째 블레이드 중심까지 거리 이고, $d \vec{F}_{d i}, d \vec{F}_{l i}, d \vec{F}_{a i}$ 는 $\mathrm{i}$ 번째 블레이드에 작용하는 저항력, 양 력, 부가 질량에 의한 힘이다. 파도에 의하여 수직운동을 하는 웨이브터빈은 늘 가속운동을 하므로 부가질량에 의한 성분이 큰 영향을 미친다.

모델링을 통해 터빈 로터의 회전에 가장 중요한 요소는 블레 이드로부터 생성되는 추력 $N_{b}$ 이다. 블레이드의 추력은 블레이 드 수 $n$ 에 직접적인 영향을 받으며, 또한 블레이드의 유체역학 적 형상에 영향을 받는다. 파도의 움직임에 따라 블레이드가 천 이 상태에서 받음각 제한 장치에 의해 고정이 되면 이때 블레 이드의 실제 받음각 $\alpha$ 은 다음과 같이 구해진다.

$$
\alpha=\tan ^{-1}\left(\frac{\dot{Z}}{r_{i} \dot{\psi}}\right)
$$

따라서 터빈의 정격 회전 속도와 파도에 따른 잠수체의 수직 방향 동적 거동에 따라 계산된 받음각에서 최적의 블레이드 형 상 설계가 가능하다.

\section{3 프레임의 항력계수 추정}

웨이브 터빈 잠수체의 프레임은 복잡한 형상으로 정확한 모 델링을 정립하는 것은 어렵다. 하지만 시뮬레이션과 유사한 조 건으로 실험을 실시하여 추정치를 계산하는 것은 가능하다. 이 를 통해 시뮬레이션의 정확도를 높일 수 있다. 상단 로터에 작 용하는 항력은 위 식 (7)에 나타난대로 $D_{u}\left(\delta_{u}, \dot{\alpha}_{u}\right)$ 로 블레이드의 받음각 한계와 회전 속도의 함수로 표현된다. $D_{u}$ 는 블레이드에 의한 항력과 프레임으로 인한 항력으로 나눠 표현할 수가 있는 데, 프레임의 항력은 식 (16)과 같이 간단히 표현할 수 있다.

$$
D_{f}=C_{d f} \dot{\psi^{2}}
$$

여기서 로터 프레임의 항력 계수 $C_{d f}$ 를 추정하기 위해 웨이브 터빈 모델링을 이용하여 시뮬레이션을 실시하였다. 시뮬레이션 에 적용한 웨이브 터빈의 조건은 Table 2와 같다.

시뮬레이션에서는 파고는 $0.3 \mathrm{~m}$, 파주기는 $[4,5,6]$ 초로 다양 하게 하였다. $C_{d f}$ 를 추정하기 위해 동일한 조건으로 실시한 실 험데이터를 활용하였다(Table 3). 시뮬레이션 결과 $C_{d f}$ 가 증가할 수록 로터의 회전 속도 변화는 Fig. 12에 나타내었다.

Fig. 13 에 의하면 시뮬레이션과 실험결과로 추정한 $C_{d f}$ 는 각 


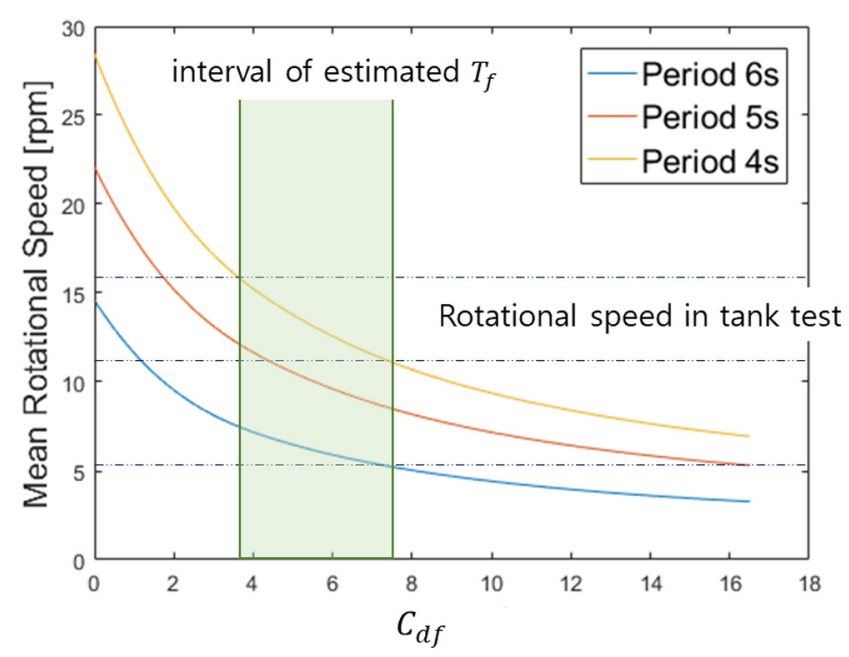

Fig. 12 An example of rotational speed variation with change of drag coefficient of rotor frame

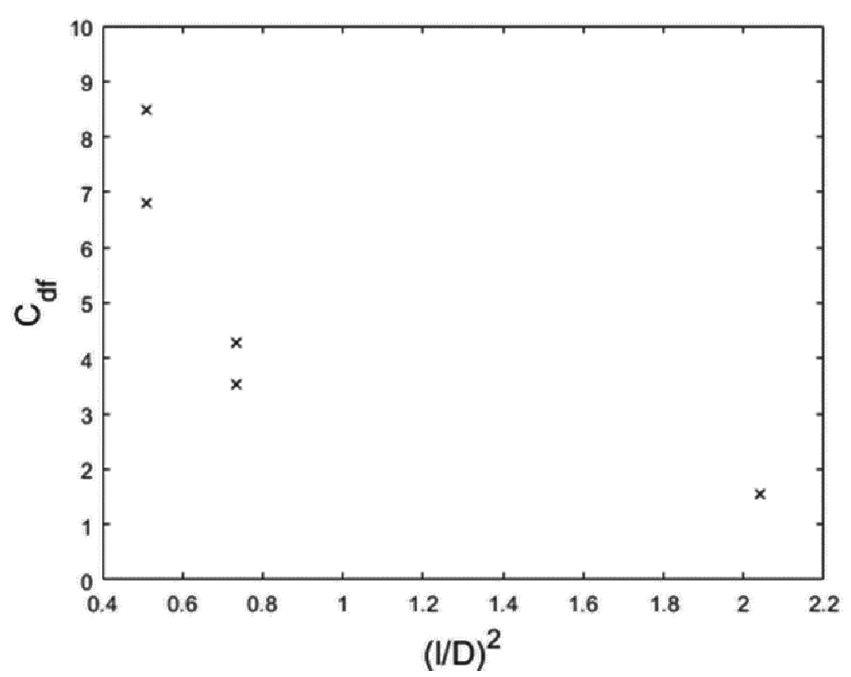

Fig. 13 Relation between drag coefficient of frame and quadratic blade length ratio with frame diameter

케이스 별로 $3.52,1.54,8.49,6.79$ 로 나타났다. 여기에 블레이드 길이를 프레임의 직경으로 나눠 무차원화 시킨 값을 비교하면, 블레이드 길이와 프레임 직경간의 비율의 제곱에 반비례함이 나타난다. 이는 같은 프레임직경에서도 블레이드의 길이가 길 면 프레임에 의한 항력이 감소하는 것을 의미한다. 블레이드가 주변 물를 함께 회전시키면서 실질적으로 프레임에 가해지는 저항이 줄어드는 것으로 생각된다(Roh et al., 2016). 이 현상은 Fig. 12 를 통해서도 나타나는데, 파도의 주기를 4초에서 6초로 빠르게 하는 실험에서 계측한 회전 속도와 실험과 동일한 조건 에서 $C_{d f}$ 를 변화시켜가며 시뮬레이션 한 결과를 비교하면 실험 에 사용한 로터 프레임의 저항 계수를 추정할 수 있다. 점선은 실제 실험에서 계측된 회전 속도를 나타내는데, 시뮬레이션 결 과와 실험 결과가 일치하는 부분이 회전속도가 빠를수록 작아 지는 것을 확인할 수 있다.

또한 $C_{d f}$ 를 조정해 가며 에너지 수급을 비교하면 블레이드의 길이가 프레임 직경에 비해 클 때 에너지 수급량이 커짐을 시

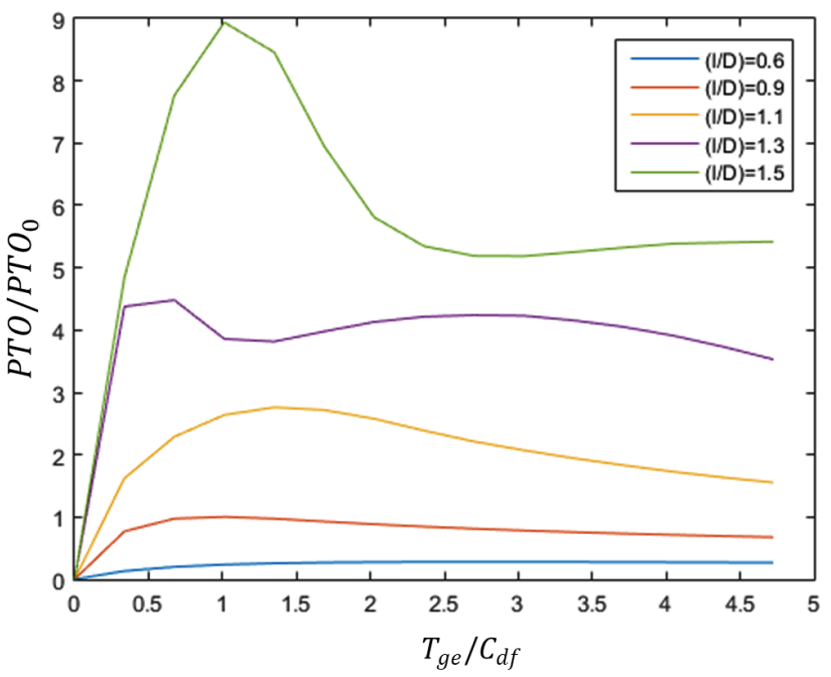

Fig. 14 Comparison of power take-off with changing drag coefficient of frame

뮬레이션을 통해 확인할 수 있었고, 프레임의 설계는 발전기 계 수와 유사한 저항계수가 산출되도록 설계를 하면 효율을 최대 화 할수 있을 것으로 보인다(Fig. 14).

최적 설계를 위한 또 다른 변수로는 블레이드의 크기, 폭, 프레 임 허브, 적정 받음각 제한 각도 등이 있다. 이는 설계 변수를 변 경하는 정량적 시뮬레이션을 통해 구할 수 있다(Joe et al., 2017).

\section{5. 결 론}

본 논문에서는 새로운 파력 발전 부이시스템을 제안하고, 핵 심인 파력발전 장치의 성능과 최적 설계방안에 대해 연구하였 다. 일반적인 파력발전 장치의 경우 해저면에 계류되거나 구조 물로 설치되어야 하는 단점이 있는데, 제안하는 파력발전 장치 웨이브 터빈은 계류하지 않고 파도의 운동을 회전운동으로 변 환이 가능하다. 이를 하드웨어 프로토 타입을 개발하여 증명 하 였고, 다양한 환경에서 성능 테스트를 실시하였다. 테스트 결과 를 기반으로 하여 최적 설계를 위한 주요 설계 변수 선정 방법 을 도출해 내었다. 웨이브 터빈은 파도의 상하 움직임에서 모두 전력이 생성 가능한 장점이 있으나 생성 전력이 파도의 상태에 따라 아주 불규칙하다는 단점이 있다. 불규칙한 전력 수급은 파 력 발전장치의 근원적인 문제이므로 이를 극복하기 위해 기계 적 또는 전기적인 에너지 저장장치 설계가 필요하다. 향후 연구 에서는 최적의 웨이브 터빈을 제작하고, 이동체에 부착하여 이 동 간에 에너지 수급변화를 연구할 계획이다.

$$
\text { 후기 }
$$

본 연구는 미해군 고등기술연구소 ONR Global의 연구 지원금 N62909-13-1-N173으로 수행되었습니다(This project was supported by Office of Naval Research Grant N62909-13-1-N173). 또한 해양 수산부가 후원하는 “경북씨그랜트 프로그램”과 과학기술정보통 신부 및 정보통신기술진흥센터의 ICT명품인재양성사업(IITP-20182011-1-00783)의 지원으로 수행되었습니다. 


\section{References}

Bingham, B., Kraus, N., Howe, B., Freitag, L., Ball, K., Koski, P., Gallimore, E., 2012. Passive and Active Acoustics using an Autonomous Wave Glider. Journal of Field Robotics, 29(6), 911-923.

Daniel, T., Manley, J., Trenaman, N., 2011. The Wave Glider: Enabling a New Approach to Persistent Ocean Observation and Research. Ocean Dynamics, 61(10), 1509-1520.

Dean, R.G., Dalrymple, R.A., 1991. Water Wave Mechanics for Engineers and Scientists (Vol. 2). World Scientific Publishing Company.

Falnes, J., 2007. A Review of Wave-Energy Extraction. Marine Structures, 20(4), 185-201.

Hine, R., Willcox, S., Hine, G., Richardson, T., 2009. The Wave Glider: A Wave-powered Autonomous Marine Vehicle. In OCEANS 2009, MTS/IEEE Biloxi-Marine Technology for Our Future: Global and Local Challenges, 1-6.
Joe, H., Roh, H., Pyo, J., Gu, J., Kim, J., Kim, B.J., Yu, S.C., 2015. Development of Energy-harvesting Unit and Propulsion Unit for a Robotic Buoy System. In OCEANS'15 MTS/IEEE Washington, 1-6.

Joe, H., Roh, H., Cho, H., Yu, S.C., 2017. Development of a Flap-type Mooring-less Wave Energy Harvesting System for Sensor Buoy. Energy, 133, 851-863.

McCormick, M.E., 1973. Ocean Engineering Wave Mechanics. John Wiley \& Sons.

Roh, H., Joe, H., Song, S., Sung, M., Yu, S.C., 2016. Hydrodynamic Modeling and Optimization of Mobile Wave Energy Harvesting System for the Robotic Buoy. In OCEANS 2016 MTS/IEEE Monterey, 1-4.

Smil, V., 2008. Energy in Nature and Society: General Energetics of Complex Systems. MIT Press.

Willcox, S., Manley, J., Wiggins, S., 2009. The Wave Glider, an Energy Harvesting Autonomous Surface Vessel. Sea Technology, 49, 29-31. 